Bull. Chem. Soc. Ethiop. 2019, 33(3), 573-578.

ISSN 1011-3924

(c) 2019 Chemical Society of Ethiopia and The Authors

Printed in Ethiopia

DOI: https://dx.doi.org/10.4314/bcse.v33i3.17

\title{
LEVELS OF MERCURY AND ARSENIC CONTAMINATION IN POPULAR FISH AND SHRIMP BRANDS CONSUMED IN SAUDI ARABIA
}

\author{
M. Waqar Ashraf ${ }^{*}$ and Atiq Mian ${ }^{2}$ \\ ${ }^{1}$ Department of Natural Sciences \& Mathematics, Prince Mohammad Bin Fahd University, Al \\ Khobar 31952, Kingdom of Saudi Arabia \\ ${ }^{2}$ Center for Environment \& Water, King Fahd University of Petroleum \& Minerals, Dhahran \\ 31261, Kingdom of Saudi Arabia
}

(Received July 20, 2018; Revised April 18, 2019; Accepted July 3, 2019)

\begin{abstract}
Fish and shrimp are public sources of healthy protein for a large fragment of the Saudi population. Therefore, the present work was conducted to assess the level of possible arsenic (As) and mercury $(\mathrm{Hg}$ ) contamination of these sea foods. Eight species of fish and two species of shrimp were collected from the local markets of Eastern Province, Saudi Arabia. Mercury and arsenic concentration of samples was determined by hydride generation atomic absorption spectrometry (HG-AAS). Highest average concentration of total $\mathrm{Hg}$ was found in Siganus canaliculatus $(0.54 \pm 0.06 \mu \mathrm{g} / \mathrm{g})$ while the lowest level was detected in Lethrinus miniatus $(0.24$ $\pm 0.07 \mu \mathrm{g} / \mathrm{g}$ ). For shrimp species, the levels varied from 0.13 to $0.91 \mu \mathrm{g} / \mathrm{g}$ for mercury and 0.19 to $0.53 \mu \mathrm{g} / \mathrm{g}$ for arsenic. The rank order of shrimp species based upon mercury level was Penaeus semisulcatus > Penaeus indicus; whereas based upon arsenic level it was almost similar. Mean levels of both $\mathrm{Hg}$ and $\mathrm{As}$ in all the species studied are lower than the limits set by international health agencies; $0.550 \mu \mathrm{g} / \mathrm{g}$ for mercury and $6.0 \mu \mathrm{g} / \mathrm{g}$ for arsenic.
\end{abstract}

KEY WORDS: Arabian Gulf, Fish, Shrimp, Arsenic, Mercury

\section{INTRODUCTION}

Fish and shrimp are low-cost sources of healthy protein for human consumption that provide omega-3 fatty acids to reduce low density lipoproteins (LDL) levels in the blood stream and the occurrence of stroke and coronary diseases [1]. In the Gulf countries, fish and shrimp are the most important source of nutritional protein. In spite of well-known health benefits of sea food ingestion, there are many reports on its contamination by heavy metals. Toxic metals like mercury and arsenic enter marine animals such as fish and shellfish by absorption through gills or food. It is well recognized that highly contaminated fish and shrimp can produce hazardous effects to human health [2]. Since past few decades, there has been significant interest in evaluating the concentrations of heavy metals in the marine biota and sea food sources, particularly shrimp and fish. Focus has been on mercury because of its wide distribution in the aquatic environment, high tendency for bio-magnification, resistance to biodegradation and detrimental effects on aquatic life and human well being. Mercury finds its way to the environment from the combustion of fossil fuels and by industrial operations such as casting and incineration [3, 4]. High levels of mercury found in the food chain can lead to serious health issues. Well known Minamata disaster, which occurred among residents of Minamata Island in Japan, was caused by the consumption of fish and shrimp containing high levels of methylmercury. Mercury and arsenic consumption via polluted sea food has also been reported in many other parts of the world, such as Brazil, Iraq and Canada [5, 6]. The common industrial sources of arsenic into water bodies and sediments include mining, metallurgy, metal-enriched slages, manufacturing processes, coal burning power plants, urban runoff, air depositions, land reclaim and rapidly increasing urbanizing along the coastal lines $[7,8]$.

*Corresponding author. E-mail: mashraf@pmu.edu.sa

This work is licensed under the Creative Commons Attribution 4.0 International License 
Fish are known to have elevated mercury levels than any other foodstuff, although it is hard to predict exact concentration, because it depends on species, weight, age, and living environment of the fishes [9-11]. Mercury accumulation in fish and shrimp depends upon the properties of the aquatic environment such as the available chemical form of $\mathrm{Hg}$, ambient temperature and $\mathrm{pH}[12,13]$. It has been shown that the presence of mercury in fish and shrimp can pose a serious threat to the health of pregnant women and newborn [14, 15].

The Kingdom of Saudi Arabia, in general, and the Eastern Province in particular, has experienced vast social, economic, and urban development during the last two decades. This development is reflected in the industrial and agricultural sectors, the size of coastal population centers and spread of public services and facilities. However, this vast development was accompanied by several activities that have caused and continue to cause general environmental challenges particularly those related to marine environment. Land filling, disposal of industrial and domestic wastes, and oil spills are among the activities that have negatively impacted the marine environment. The average depth of the Gulf is about $35 \mathrm{~m}$, and it is almost land-locked. The turnover and flushing time has been estimated to be in the range of 3 to 5 years. Therefore, pollutants entering the Gulf are likely to reside there for substantial period of time [16]. In Saudi Arabia, approximately $40 \%$ of the coastal belt has been developed by land reclamation. Residential and commercial complexes have been made along the coast, particularly Jubail, Dammam and Al Khobar. These areas of shallow sub-tidal coast are highly productive and form nursery and feeding grounds for most commercial fish and shrimp species. The increase in population density along the coastal areas has increased the discharge of many domestic and industrial waste effluents into the Gulf water.

Despite the ecological and commercial importance of the Arabian Gulf, only a few studies had been carried out to assess mercury and arsenic in fish and shrimp [17, 18]. The fisheries of the Gulf, particularly for shrimp, are of global as well as regional importance. Recently many fishery authorities of Gulf countries have indicated a loss of fisheries potential due to anthropogenic activities along coastal lines. Such activities have negatively affected biodiversity, habitats and fish stocks. The present study is conducted with an aim to measure total mercury and arsenic levels in fish and shrimp species commonly consumed in the Saudi Arabia and exported to neighboring countries. The results of the investigation were used to determine whether the consumption of fish and shrimp can pose potential threat to the health of consumers.

\section{EXPERIMENTAL}

The sampling was conducted from hypermarkets and seafood outlets all over the Eastern Province. Eight different species of fish and two species of shrimps were selected. A total number of 54 fish samples and 29 shrimp samples were randomly procured, wrapped in labelled plastic bags and kept frozen at $-20^{\circ} \mathrm{C}$ until analyzed. The length and weight of the samples was also measured and is mentioned in Table 1.

All the reagents used in the present study were of analytical grade purchased from E. Merck, Germany. Doubly distilled high-purity water was used for the sample preparation, and all the solutions were stored in clean Pyrex glassware. Prior to analysis, all laboratory glassware were soaked in $5 \% \mathrm{HNO}_{3}$ solution for at least $24 \mathrm{~h}$ and subsequently rinsed four times with deionized water.

About $0.50 \mathrm{~g}$ of homogenized muscle samples were weighed in Pyrex beakers and $15 \mathrm{~mL}$ aliquot of mixed acids solution $\left(\mathrm{HNO}_{3}-\mathrm{H}_{2} \mathrm{SO}_{4}-\mathrm{HClO}_{4}-\mathrm{H}_{2} \mathrm{O}\right.$ in the ratios of 5:2:2:2) was added. The samples were heated for one hour in a boiling water bath till a clear solution was obtained. Digested samples were then diluted to $50 \mathrm{~mL}$ by adding deionized water. The resulting solution was filtered to remove any suspended particulate matter [19]. 
The stock solutions of $\mathrm{Hg}$ and $\mathrm{As}(1000 \mathrm{mg} / \mathrm{L})$ were prepared by dissolving accurate amounts of the metal salts (E. Merck). The working standards were freshly prepared by suitable dilutions. This was done by using $1.0 \mathrm{M} \mathrm{HCl}$ and $5 \% \mathrm{H}_{2} \mathrm{SO}_{4}$ for mercury dilution and $7.0 \mathrm{M} \mathrm{HCl}$ for arsenic dilution. Stannous chloride for mercury analysis was freshly prepared by dissolving $10 \mathrm{~g}$ of $\mathrm{SnCl}_{2}$ in $100 \mathrm{~mL}$ of $6 \mathrm{M} \mathrm{HCl}$. The resulting solution was boiled, cooled and nitrogen gas bubbled through to remove any volatile mercury impurities [20].

Arsenic and mercury were determined in all the digested samples by using atomic absorption spectrophotometer coupled with flow injection mercury/arsenic hydride analyzer (Agilent VGA 77 USA). Mercury and arsenic were determined at the wavelengths of 253.6 and $248.3 \mathrm{~nm}$, respectively. Each sample was run in triplicate and the validity of the current method was checked by spiking the samples with known quantities of mercury and arsenic. Percentages of the concentrations recovered are mentioned in Table 1.

Table 1. Characteristics of fish and shrimp species along with levels of As and Hg.

\begin{tabular}{|c|c|c|c|c|c|c|c|c|}
\hline Fish species & \begin{tabular}{|c|}
$\begin{array}{c}\text { Common } \\
\text { name }\end{array}$ \\
\end{tabular} & $\mathrm{n}$ & $\begin{array}{l}\text { Length } \\
(\mathrm{cm})\end{array}$ & Weight (g) & $\mathrm{Hg}(\mu \mathrm{g} / \mathrm{g})$ & Range & As $(\mu \mathrm{g} / \mathrm{g})$ & Range \\
\hline \multirow[t]{2}{*}{ Scarus Ghabon } & \begin{tabular}{|c|} 
Bluebarred \\
Parrot fish
\end{tabular} & 7 & $36.6-71.6$ & $358-566$ & $0.51 \pm 0.13$ & $0.14-0.98$ & $0.33 \pm 0.29$ & $0.24-0.51$ \\
\hline & & & $51.2 \pm 14.2$ & $560 \pm 32$ & & & & \\
\hline \multirow[t]{2}{*}{$\begin{array}{l}\text { Epinephelus } \\
\text { microdon }\end{array}$} & Grouper & 5 & $35.4-48.4$ & $358-779$ & $0.43 \pm 0.07$ & $0.17-0.6$ & $0.31 \pm 0.51$ & $0.12-0.39$ \\
\hline & & & $37.6 \pm 11.8$ & $419 \pm 79$ & & & & \\
\hline \multirow[t]{2}{*}{\begin{tabular}{|l} 
Epinephelus \\
coioides
\end{tabular}} & $\begin{array}{l}\text { Orange } \\
\text { Spotted } \\
\text { Grouper }\end{array}$ & 8 & $43.7-51.0$ & $421-680$ & $0.49 \pm 0.11$ & $0.11-0.86$ & $0.51 \pm 0.23$ & $0.17-0.62$ \\
\hline & & & $49.2 \pm 10.3$ & $545 \pm 66$ & & & & \\
\hline \multirow[t]{2}{*}{$\begin{array}{l}\text { Epinephelus } \\
\text { tauvina }\end{array}$} & $\begin{array}{l}\text { Greasy } \\
\text { Grouper }\end{array}$ & 9 & $42.9-55.3$ & $516-657$ & $0.52 \pm 0.08$ & $0.24-1.10$ & $0.41 \pm 0.32$ & $0.11-0.59$ \\
\hline & & & $45.9 \pm 12.0$ & $586 \pm 89$ & & & & \\
\hline \multirow[t]{2}{*}{\begin{tabular}{|l|}
$\begin{array}{l}\text { Acanthoparagus } \\
\text { bifasciatus }\end{array}$ \\
\end{tabular}} & $\begin{array}{c}\text { Doublebar } \\
\text { Bream }\end{array}$ & 5 & $25.8-42.6$ & $268-379$ & $0.42 \pm 0.04$ & $0.16-1.24$ & $0.39 \pm 0.43$ & $0.24-0.53$ \\
\hline & & & $37.9 \pm 14.3$ & $321 \pm 57$ & & & & \\
\hline \multirow[t]{2}{*}{\begin{tabular}{|l|} 
Siganus \\
canaliculatus
\end{tabular}} & Rabbit fish & 7 & $15.1-19.0$ & $93.2-319$ & $0.54 \pm 0.06$ & $0.15-0.88$ & $0.57 \pm 0.40$ & $0.35-0.61$ \\
\hline & & & $14.2 \pm 1.8$ & $1245 \pm 36$ & & & & \\
\hline \multirow[t]{2}{*}{\begin{tabular}{|l}
$\begin{array}{l}\text { Lethrinus } \\
\text { miniatus }\end{array}$ \\
\end{tabular}} & Emperors & 6 & 25.4-30.9 & $229-266$ & $0.24 \pm 0.07$ & $0.26-0.92$ & $0.41 \pm 0.29$ & $0.21-0.55$ \\
\hline & & & $26.7 \pm 5.2$ & $246 \pm 35$ & & & & \\
\hline \multirow[t]{2}{*}{\begin{tabular}{|l|} 
Lethrinus \\
nebulosus
\end{tabular}} & $\begin{array}{l}\text { Spangled } \\
\text { Emperor }\end{array}$ & 7 & $21.6-32.4$ & $199-246$ & $0.35 \pm 0.06$ & $0.32-0.89$ & $0.49 \pm 0.36$ & $0.36-0.58$ \\
\hline & & & $25.3 \pm 5.1$ & $220 \pm 20$ & & & & \\
\hline \multicolumn{9}{|l|}{\begin{tabular}{|l} 
Shrimp species \\
\end{tabular}} \\
\hline \multirow{2}{*}{ Penaeus indicus } & $\begin{array}{l}\text { Indian } \\
\text { Prawn }\end{array}$ & 12 & $9.5-16$ & $90-130$ & $0.29 \pm 0.03$ & $0.13-0.74$ & $0.25 \pm 0.16$ & $0.19-0.38$ \\
\hline & & & $13.2 \pm 3.5$ & $87 \pm 24$ & & & & \\
\hline \multirow[t]{2}{*}{$\begin{array}{l}\text { Penaeus } \\
\text { semisulcatus }\end{array}$} & $\begin{array}{c}\text { Green } \\
\text { Tiger } \\
\text { Prawn }\end{array}$ & 17 & $11-19.5$ & $95-160$ & $0.37 \pm 0.05$ & $0.19-0.91$ & $0.29 \pm 0.47$ & $0.27-0.53$ \\
\hline & & & $15.2 \pm 4.2$ & $110 \pm 45$ & & & & \\
\hline
\end{tabular}

\section{RESULTS AND DISCUSSION}

A total of 54 fish samples and 29 shrimp samples were analyzed for total mercury and arsenic contents. The results are mentioned in Table 1 and Figure 1 . The results revealed that the levels 
varied from 0.11 to $1.24 \mu \mathrm{g} / \mathrm{g}$ for mercury and 0.11 to $0.61 \mu \mathrm{g} / \mathrm{g}$ for arsenic in the fish species studied. For shrimp species, the levels varied from 0.13 to $0.91 \mu \mathrm{g} / \mathrm{g}$ for mercury and 0.19 to $0.53 \mu \mathrm{g} / \mathrm{g}$ for arsenic. Mean levels for $\mathrm{Hg}$ and As in fish species were found to be $0.44 \mu \mathrm{g} / \mathrm{g}$ and $0.42 \mu \mathrm{g} / \mathrm{g}$; whereas the levels were $0.33 \mu \mathrm{g} / \mathrm{g}$ and $0.27 \mu \mathrm{g} / \mathrm{g}$ in shrimp, respectively. Mean levels of both $\mathrm{Hg}$ and As in all the species studied are lower than the limits set by international health agencies; $0.55 \mu \mathrm{g} / \mathrm{g}$ for mercury and $6.0 \mu \mathrm{g} / \mathrm{g}$ for arsenic [21, 22]. The rank order of shrimp species based upon mercury level was Penaeus semisulcatus $>$ Penaeus indicus; whereas based upon arsenic level it was almost similar.

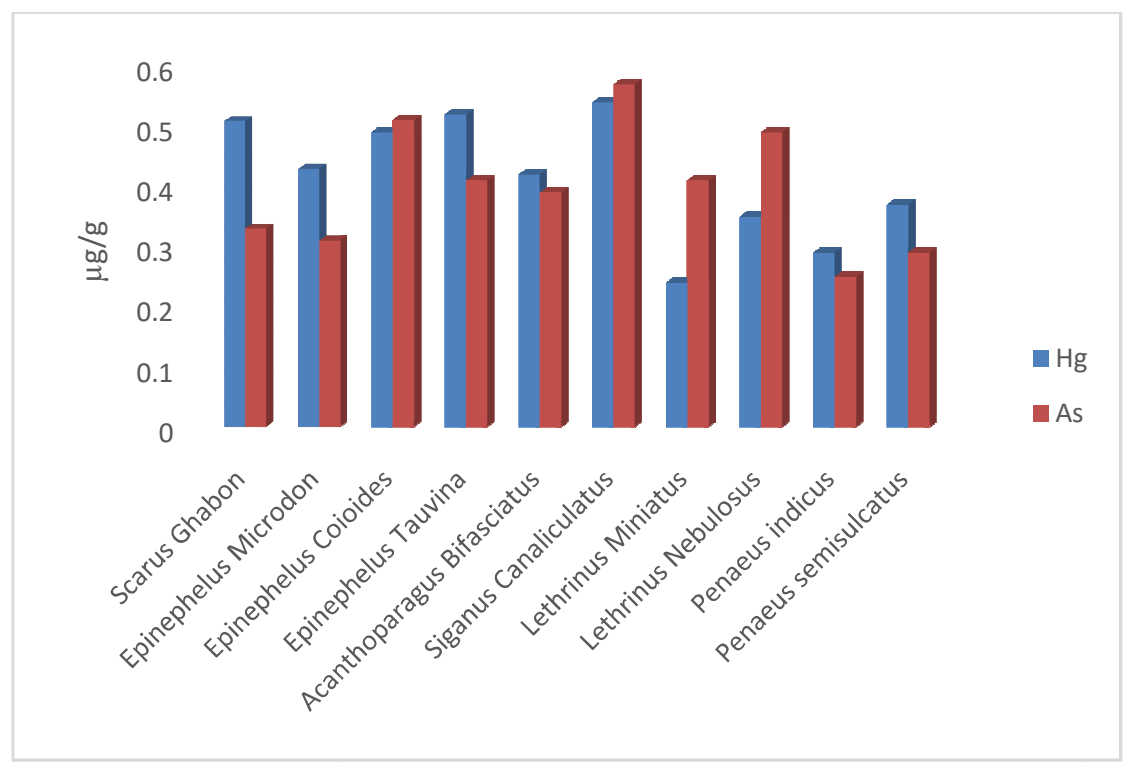

Figure 1. Levels of $\mathrm{Hg}$ and $\mathrm{As}$ in fish and shrimp species.

Both mercury and arsenic have been documented as toxic environmental pollutants even at trace levels. Mercury accumulates in marine food chain and about $95 \%$ of methylmercury contamination in human beings originates from sea food consumption [4, 8]. Methylmercury is classified as a possible group $\mathrm{C}$ human carcinogen and neurological toxicant [21].

During a study carried out in the South Korea [24] where As levels in shrimp species, Acetes japonicas, Fenneropenaeus chinensis, and Metapenaeus joyneriranged between $1.12 \pm 1.57$, $0.997 \pm 1.08$, and $3.56 \pm 2.96 \mathrm{mg} / \mathrm{kg}$, respectively; and the average levels were $1.87 \pm 1.82$ $\mathrm{mg} / \mathrm{kg}$; these values was similar to our results from the Arabian Gulf despite of difference in the species of shrimp.

European Commission have set the maximum limit for mercury in seafood at $0.5 \mu \mathrm{g} / \mathrm{g}$ for fresh food, increasing to $1.0 \mu \mathrm{g} / \mathrm{g}$ for the muscular part of some listed species that accumulate more mercury in their tissues because of metabolic reasons [21, 25]. However, the efficacy of metal accumulation from the contaminated water may be different because of ecological needs, metabolism and physicochemical characteristics of water such as salinity, temperature, BOD and COD [20].

Benthic species are known to accumulate heavy metals from water and sediments $[23,26]$. Shrimp and other crustaceans have different routes for bioaccumulation of pollutants, such as absorption at the gill surface, ingestion of contaminated sediments, and feeding on the 
organisms which themselves have accumulated these pollutants in their tissues [27]. Therefore, variations in the levels of $\mathrm{As}$ and $\mathrm{Hg}$ in the tissues of fish and shrimp consumed in Saudi Arabia were broadly comparable to those found in similar national and international studies.

\section{ACKNOWLEDGEMENTS}

Authors are thankful to Deanship of Research, Prince Mohammad Bin Fahd University for supporting the present work. Thank is also due to Research Institute KFUPM for the provision of $\mathrm{Hg}$ and $\mathrm{As}$ standards and inter laboratory comparison of data.

\section{REFERENCES}

1. Ahmed, M.K.; Baki, M.A.; Islam, M.S.; Kundu, G.K.; Habibullah-Al-Mamun, M.; Sarkar, S.K. Human health risk assessment of heavy metals in tropical fish and shellfish collected from the river Buriganga, Bangladesh. Environ. Sci. Pollut. Res. 2015, 22, 15880-15890.

2. Ololade, I.A.; Lajide, L.; Olumekun, V.O.; Ololade, O.O.; Ejelonu, B.C. Influence of diffuse and chronic metal pollution in water and sediments on edible sea foods within Ondo oilpolluted coastal region, Nigeria. J. Environ. Sci. Health Part A 2011, 46, 898-908.

3. Itanna, F. Comparative study on soil pollution with toxic substances of farmlands close to old and new industrial sites in Ethiopia. Bull. Chem. Soc. Ethiop. 1998, 12, 105-112.

4. Yuan, L.; Guijian, L.; Zijiao, Y.; Houqi, L.; Paul, K.S. Presence of arsenic, mercury and vanadium in aquatic organisms of Laizhou Bay and their potential health risk. Marine Pollut. Bull. 2017, 25, 334-340.

5. Yadolah, F.; Anoushiravan, M.; Gea O.; Margherita F.; Antonio C.; Ali Khani J.; Maryam K. D.; Abdolazim A.; Hassan R.; Seyed M. M.; Maryam S.; Hassan K.; Bigard M.; Nazak A.; Zahra B. Systematic review and health risk assessment of arsenic and lead in the fished shrimps from the Persian Gulf. Food Chem. Toxicol. 2018, 113, 278-286.

6. Olmedo, A.P.; Hernández, A.F.; Barbier, F.; Ayouni, L.; Gil, F. Determination of toxic elements (mercury, cadmium, lead, tin and arsenic) in fish and shellfish samples. Risk assessment for the consumers. Environ. Int. 2013, 59, 63-72.

7. Liu, J.; Xu, X.; Yu, S.; Cheng, H.; Hong, Y.; Feng, X. Mercury pollution in fish from South China Sea: Levels, species-specific accumulation, and possible sources. Environ. Res. 2014, 131, 160-164.

8. Tao, H.C.; Zhao, K.Y.; Ding, W.Y.; Li, J.B.; Liang, P.; Wu, S.C.; Wong, M.H. The level of mercury contamination in mariculture sites at the estuary of Pearl River and the potential health risk. Environ. Pollut. 2016, 219, 829-836.

9. Wong, M.H. Chemical pollution and seafood safety, with a focus on mercury: the case of Pearl River Delta, South China. Environ. Technol. Innov. 2017, 7, 63-76.

10. Goutte, A.; Cherel, Y.; Churlaud, C.; Ponthus, J.P.; Masse, G.; Bustamante, P. Trace elements in Antarctic fish species and the influence of foraging habitats and dietary habits on mercury levels. Sci. Total Environ. 2015, 538, 743-749.

11. Mohammad, A.B.; Muzammel, H.; Jhuma, A.; Shamshad, B.Q.; Fajlul, H.S.; Atique Ullah, A.K.M.; Firoz, K.M. Concentration of heavy metals in seafood (fishes, shrimp, lobster and crabs) and human health assessment in Saint Martin Island, Bangladesh. Ecotoxicol. Environ. Safety 2018,159, 153-163.

12. Dsikowitzky, L.; Mengesha, M.; Dadebo, E.; de Carvalho, C.E.; Sindern, S. Assessment of heavy metals in water samples and tissues of edible fish species from Awassa and Koka Rift Valley Lakes, Ethiopia. Environ. Monit. Assess. 2013, 185, 3117-3131. 
13. Tommaso F. Intake of arsenic and mercury from fish and seafood in a Northern Italy Community. Food Chem. Toxicol. 2018, 116, 20-26.

14. Turkmen, G. Seasonal variation of heavy metals in shrimp Penaeus kerathurus (forskal, 1775) from Izmir Bay, Turkey. J. Animal Vet. Adv. 2012, 11, 2839-2844.

15. Xu, L.; Ji, C.; Zhao, J.; Wu, H. Metabolic responses to metal pollution in shrimp Crangon affinis from the sites along the Laizhou Bay in the Bohai Sea. Marine Pollut. Bull. 2016, $113,536-541$.

16. Ashraf, W.; Nazeer, Z. Heavy metals burden in kidney and heart tissues of Scarus ghobban fish from the Eastern province of Saudi Arabia. Bull. Chem. Soc. Ethiop. 2010, 24, 139-143.

17. Al-Saleh, I.; Al-Doush, I. Mercury content in shrimp and fish species from the Gulf Coast of Saudi Arabia. Bull. Environ. Contam. Toxicol. 2002, 68, 576-583.

18. Sadiq, M.; Zaidi, T.H. Metal concentrations in the sediments from the Arabian Gulf coast of Saudi Arabia. Bull. Environ. Contam. Toxicol. 1985, 34, 565-571.

19. Ozden, O. Seasonal differences in the trace metal and macrominerals in shrimp (Parapenaus L. ongirostris) from Marmara Sea. Environ. Monit. Assess. 2010, 162, 191-199.

20. Raissy, M.; Ansari, M. Health risk assessment of mercury and arsenic associated with consumption of fish from the Persian Gulf. Environ. Monit. Assess. 2014, 186, 1235-1240.

21. US EPA, U.S. Environmental Protection Agency. Guidance for Assessing Chemical Contaminant Data for Use in Fish Advisories, Volume II. Risk Assessment and Fish Consumption Limits. (EPA 823-B-00-008). United States Environmental Protection Agency: Washington, DC.; 2000.

22. Husain, A.; Kannan, K.; Chan, H.M.; Laird, B.; Al-Amiri, H.; Dashti, B.; Sultan, A.; AlOthman, A.; Mandekar, B. A comparative assessment of arsenic risks and the nutritional benefits of fish consumption in Kuwait: arsenic versus omega 3-fatty acids. Arch. Environ. Contam. Toxicol. 2017, 72, 108-118.

23. Wu, B.; Song, J.; Li, X. Evaluation of potential relationships between benthic community structure and toxic metals in Laizhou Bay. Marine Pollut. Bull. 2014, 87, 247-256.

24. Habte, G.; Ji Yeon, C.; Eun Yeong, N.; Sang, Y.; Naeem, K.; Hoon, C.; Kyung, Su. Determination of toxic heavy metal levels in commonly consumed species of shrimp and shellfish using ICP-MS/OES. Food Sci. Biotechnol. 2015, 24, 373-378.

25. JECFA (Joint FAO/WHO Expert Committee on Food Additives), Evaluations of the Joint FAO/WHO Expert Committee on Food Additives, WHO; 2015.

26. Mendil, D.; Demirci, Z.; Tuzen, M.; Mustafa, S. Seasonal investigation of trace element contents in commercially valuable fish species from the Black sea, Turkey. Food Chem. Toxicol. 2010, 48, 865-870 .

27. Uzairu, A.; Harrison, G.F.S.; Balarabe, M.L.; Nnaji, J.C. Concentration levels of trace metals in fish and sediment from Kubanni River, Northern Nigeria. Bull. Chem. Soc. Ethiop. 2009, 23, 9-17. 